\title{
Microbially competent 3D skin: a test system that reveals insight into host-microbe interactions and their potential toxicological impact
}

\author{
Lisa Lemoine $^{1,2} \mathbb{D} \cdot$ Ralf Dieckmann $^{3} \cdot$ Sascha Al Dahouk $^{3} \cdot$ Szilvia Vincze $^{3} \cdot$ Andreas Luch $^{1,2} \cdot$ Tewes Tralau $^{4}$
}

Received: 9 March 2020 / Accepted: 9 July 2020 / Published online: 17 July 2020

(c) The Author(s) 2020

\begin{abstract}
The skin`s microbiome is predominantly commensalic, harbouring a metabolic potential far exceeding that of its host. While there is clear evidence that bacteria-dependent metabolism of pollutants modulates the toxicity for the host there is still a lack of models for investigating causality of microbiome-associated pathophysiology or toxicity. We now report on a biologically characterised microbial-skin tissue co-culture that allows studying microbe-host interactions for extended periods of time in situ. The system is based on a commercially available 3D skin model. In a proof-of-concept, this model was colonised with single and mixed cultures of two selected skin commensals. Two different methods were used to quantify the bacteria on the surface of the skin models. While Micrococcus luteus established a stable microbial-skin tissue co-culture, Pseudomonas oleovorans maintained slow continuous growth over the 8-day cultivation period. A detailed skin transcriptome analysis showed bacterial colonisation leading to up to 3318 significant changes. Additionally, FACS, ELISA and Western blot analyses were carried out to analyse secretion of cytokines and growth factors. Changes found in colonised skin varied depending on the bacterial species used and comprised immunomodulatory functions, such as secretion of IL- $\alpha / \beta$, Il-6, antimicrobial peptides and increased gene transcription of IL-10 and TLR2. The colonisation also influenced the secretion of growth factors such as VFGFA and FGF2. Notably, many of these changes have already previously been associated with the presence of skin commensals. Concomitantly, the model gained first insights on the microbiome's influence on skin xenobiotic metabolism (i.e., CYP1A1, CYP1B1 and CYP2D6) and olfactory receptor expression. The system provides urgently needed experimental access for assessing the toxicological impact of microbiome-associated xenobiotic metabolism in situ.
\end{abstract}

Keywords Microbial-skin tissue co-culture $\cdot$ Skin model $\cdot$ Commensals $\cdot$ Transcriptional changes $\cdot$ Method development

Electronic supplementary material The online version of this article (https://doi.org/10.1007/s00204-020-02841-z) contains supplementary material, which is available to authorized users.

Lisa Lemoine

Lisa.Lemoine@bfr.bund.de

1 Department of Chemical and Product Safety, German Federal Institute for Risk Assessment (BfR), Max-Dohrn-Strasse 8-10, 10589 Berlin, Germany

2 Department of Biology, Chemistry, Pharmacy, Institute of Pharmacy, Freie Universität Berlin, Berlin, Germany

3 Department of Biological Safety, German Federal Institute for Risk Assessment (BfR), Diedersdorfer Weg 1, 12277 Berlin, Germany

4 Department of Food Safety, German Federal Institute for Risk Assessment (BfR), Max-Dohrn-Strasse 8-10, 10589 Berlin, Germany

\section{Introduction}

In terms of bacterial numbers and population density our skin comes second to the gut, harbouring more than 200 different bacterial genera with an overall population density between 1 million and 1 billion cells per $\mathrm{cm}^{2}$ (Grice et al. 2008, 2009; Ross et al. 2019). Set into relation this is a significant part of our microbiome, which as such not only outnumbers us cell- and genomewise, but also features a metabolic potential far exceeding our own in terms of biochemistry as well as genetic flexibility (Possemiers et al. 2011; Sender et al. 2016; Tralau et al. 2015; Yadav et al. 2018). While still in its relative infancy and thus maybe at time overstated our understanding of the microbiome's impact on host biology continues to increase steadily. This is not the least thanks to massive parallel sequencing, metabolomics, metaproteomics and stable isotope probing-based 
approaches (Berry and Loy 2018; Isaac et al. 2019; Lamichhane et al. 2018; Turnbaugh et al. 2007). However, due to the limited choice of suitable in vitro models current studies mostly rely on analyses in situ, culture-independent approaches or, despite their restricted applicability, mouse models (Staley et al. 2017; Wang and Donovan 2015). The picture emerging from these studies shows an intricate relationship between the human host and its microbial colonists, the biological implications of which include commensalic functions such as vitamin and amino acid synthesis or immune modulation as was well as pathophysiologies such as allergies, chronic diseases, behavioural disorders or toxification of xenobiotics (Clemente et al. 2012; Platzek et al. 1999; Sowada et al. 2017; Tralau et al. 2015). The mechanisms underlying the latter are diverse and include substance-induced shifts of host microbiota composition, microbiome-catalysed chemical modifications or metabolism of xenobiotics as well as microbiome induced changes of the hosts gene expression (Collins and Patterson 2020). Traditionally, most research on microbial influence on xenobiotic metabolism has focused on the gut. Respective examples comprise more than thirty commercially available drugs, including blockbusters such as paracetamol (Clayton et al. 2009; Sousa et al. 2008; Tralau et al. 2015). At times harmless or merely affecting efficacy the corresponding consequences can also prove fatal. This has been tragically the case for sorivudine, highlighting the pressing need for a more systematic and better understanding of any potential microbial impact on toxification of drugs and chemicals (Sousa et al. 2008). Given the high metabolic potential of the various microbiomes and the fact that exposure to xenobiotics also occurs outside the gut it would be naïve, however, to restrict the search for such microbiome-associated substance-induced pathophysiologies to the gut. Indeed and albeit less well investigated in terms of potential microbiome interactions many active ingredients are, for example, also applied to skin.

Yet, detailed and systematic analysis of commensalic metabolism and its effects on host biology is often hampered as there is a lack of model systems able to emulate host-microbiome biology under controlled conditions, particularly if the aim is to move beyond the state of community analysis or measurement of basic metabolite patterns. With only a handful of systems available for the gut this is even more the case for skin. So far there is no microbially competent in vitro model commercially available that would allow skin-microbiome studies for extended periods of time.

Nevertheless, the biological relevance of such models is high and their potential applications extend well beyond toxicology. Modulation of skin inflammation, for example, is functionally dependent on commensals and the progress of inflammation depends, amongst others, on innate immune factors such as $\beta$-defensins and cathelicidin (Christensen and
Bruggemann 2014; Gallo and Hooper 2012; Lai et al. 2010; Percoco et al. 2013). Released by keratinocytes in order to kill or inactivate pathogens (Lai and Gallo 2009), the expression of these antimicrobial peptides (AMPs) depends on commensal Toll-like receptor 2 (TLR2)-activation (Lai et al. 2010). Likewise, skin commensals have been shown to induce and control $\mathrm{T}$ cell responses in mouse models (Linehan et al. 2018; Schommer and Gallo 2013). Effects observed include increased production of pro-inflammatory molecules such as interferon- $\gamma$ (INF $\gamma$ ) and interleukin (IL)-17A with the regulatory factors involved [IL-1 $\alpha$, IL-1 $\beta$, IL-6, Transforming Growth Factor (TGF)- $\beta$ ] being partly induced or regulated by skin commensals (Feehley and Nagler 2014; Hasegawa et al. 2012; Naik et al. 2012; Veldhoen et al. 2008). These cytokines are also essential for the expression of various AMPs (Huang et al. 2002; Steinz et al. 2014). However, the mechanisms underlying the respective microbial immune-modulatory function are only partly understood. Particularly bacterially triggered modulations of toll-like receptor (TLR) responses extend the link into cellular signalling cascades beyond immediate immune reactions as the physiological implications of the IL-1R/TLR superfamily not only extend to inflammation regulation but also resistance to epithelial injury and epithelial homeostasis (Barton and Medzhitov 2003; Dunne and O’Neill 2003; Kubinak and Round 2012; Lopez-Castejon and Brough 2011).

Beyond extensively characterised immunomodulation dysbiosis of the skin's microbiome has been associated with conditions such as atopic dermatitis or allergies and recent work highlighted the potential of skin commensals to form highly carcinogenic by-products from benzo $[a]$ pyrene and other polycyclic aromatic hydrocarbons (Platzek et al. 1999; Sowada et al. 2014; Stingley et al. 2010). Yet, for many of the observed microbial dysbalances it still remains unclear if they are cause or rather consequence of the respective condition (Tralau et al. 2015). Even the presumably more straightforward hazard of carcinogenic metabolites remains challenging to assess, not the least due to the aforementioned lack of suitable model systems (Sowada et al. 2014, 2017). We now report on the development of a test system designed to study skin-microbe interactions in situ. The system relies on a commercially available 3D skin model, that is EpiDermFT ${ }^{\mathrm{TM}}$ from MatTek, which consists of epidermal and dermal layers, that are mitotically and metabolically active and exhibit in vivo-like morphological and growth characteristics which are uniform and highly reproducible. Moreover, the model was previously pre-validated for metabolically competent toxicity testing in vitro (Brinkmann et al. 2013; Hu et al. 2010) and genotoxicity testing using micronucleus and COMET assays (Pfuhler et al. 2014). In a proof-of-concept, this model has now been colonised using two previously isolated skin isolates, namely Micrococcus 
luteus 1B and Pseudomonas oleovorans 1C (Sowada et al. 2014). The selection of these organisms followed practical considerations and with the intended later application of studying potential microbiome-mediated substance toxification in mind. Both species are biologically relevant (Chiller et al. 2001; Wang et al. 2019), have an established potential for xenobiotic metabolism (Egea et al. 2017; Hanafy et al. 2016; Sowada et al. 2014; Viggor et al. 2020) and have been isolated repeatedly from healthy volunteers at different sites (Khayyira et al. 2020; Sowada et al. 2014; Steglinska et al. 2019; Wang et al. 2019). Amongst the skin's Micrococcaceae M. luteus is the predominant species (Chiller et al. 2001). It is considered essential for the population balance of the skin's microbiome (Epstein 2015) and usually accounts for $20-80 \%$ of the micrococci isolated (Davis 1996). Correspondingly $P$. oleovorans belongs to the Proteobacteria which make up to $34 \%$ of the whole skin microbiome (Kim et al. 2018). Lastly, both organisms bring the added bonus of being aerobes belonging to different Gram-categories which eases their laboratory handling.

The aim of this work was to develop a microbially competent skin model that provides access to microbe-host interactions and the toxicological impact of microbiome-mediated metabolism of xenobiotics under near in vivo conditions. Any such model has to be functional for at least 1 week in order to also pick up on slow or delayed xenobiotic modulations. Model functionality thus crucially depends on comparing its biology with what has been reported for commensalic skin interactions previously.

\section{Results}

Two representative skin commensals were tested for stable colonisation of commercially available 3D skin models in a proof of concept study. Based on its performance in toxicological prevalidation studies the model of choice was EpiDermFT ${ }^{\mathrm{TM}}$ as distributed by MatTek (Brinkmann et al. 2013). The model was tested with two bacterial strains, the Gram-negative P. oleovorans and the Gram-positive $M$. luteus, both of which were previously isolated from healthy volunteers (Sowada et al. 2014).

\section{Establishment of stable microbial-skin tissue co-cultures}

First tests focused on establishing microbial-skin tissue cocultures using single strains or a mixed culture. Following bacterial inoculation the corresponding skin models were maintained over a period of 8 days with sampling performed on days 0,4 and 8. Microbial-skin tissue co-culture formation and stability was followed by colony counts and strainspecific qPCR. Single cultures as well as the mixed culture viable colony counts $\left(\mathrm{CFU} / \mathrm{cm}^{2}\right)$ showed microbial-skin tissue co-culture establishment to occur during the first 4 days with bacterial cell numbers of $M$. luteus remaining largely stable thereafter (Fig. 1a). However, in both culture scenarios (single vs. mixed culture) $P$. oleovorans repeatedly reached higher cell numbers. In the mixed culture this resulted in $P$. oleovorans outcompeting $M$. luteus, the latter growing in lower numbers than when cultured alone (Fig. 1b, c). Strain-specific real-time quantitative PCR (data not shown) confirmed this data.

Microscopy and Gram-staining was concomitantly used to visualise bacterial colonisation in situ. The respective slides showed $M$. luteus to exclusively stay on the surface of the skin, whereas $P$. oleovorans appears partially to penetrate into the (epi)dermal layers (Supplementary Fig. S3a). Moreover, and in line with the CFU-data the slides visually confirmed $P$. oleovorans to outnumber $M$. luteus in microbial-skin tissue co-culture (Supplementary Fig. S3b). None of the recordings indicated any cross-contamination or foreign contamination with microorganisms. This was also confirmed by supplementary 16S-PCR and sequencing.

\section{Impact of bacterial co-colonisation on skin model biology}

Next the impact of microbial co-colonisation on the skin models was assessed. For this purpose, Human Clariom ${ }^{\mathrm{TM}}$ $\mathrm{S}$ assays were subsequently used to record transcriptomic profiles of models colonised with M. luteus or P. oleovorans. The assay provides a transcriptomic snapshot of a core-set of 20,000 well-annotated genes, thus allowing a basic functional assessment of the skin's global gene expression and molecular network interactions prior and after microbial colonisation. Co-colonisation had a clear effect on the skin with principal component analysis differentiating the untreated controls from the microbially competent models (Fig. 2a). In total 313 and 3318 transcripts were found to be specifically affected by the presence of $M$. luteus and $P$. oleovorans, respectively (Fig. 2b).

Preliminary functional IPA analysis indicated reduced cell death and moderate effects on cell growth, proliferation and tissue development, including vasculogenesis (Supplementary Fig. S4). Although the underlying transcriptional changes occurred with both strains, the effectual tendencies were more pronounced with $P$. oleovorans. In depth analysis showed most of the affected transcripts to relate to immune functions with the AMPs defensin $\beta 4 \mathrm{~A}$ and $\mathrm{B}$ being amongst the most differentially regulated genes (Fig. 3a). Befittingly increased levels of defensin $\beta$ 4A were also detected in the culture supernatant (Fig. 3b). Other AMPs such as Cathelicidin-related antimicrobial peptides (CAMP) or RNase7 were not found to be differentially expressed. Nevertheless, IPA analysis showed high activity of CAMP-regulated transcripts 


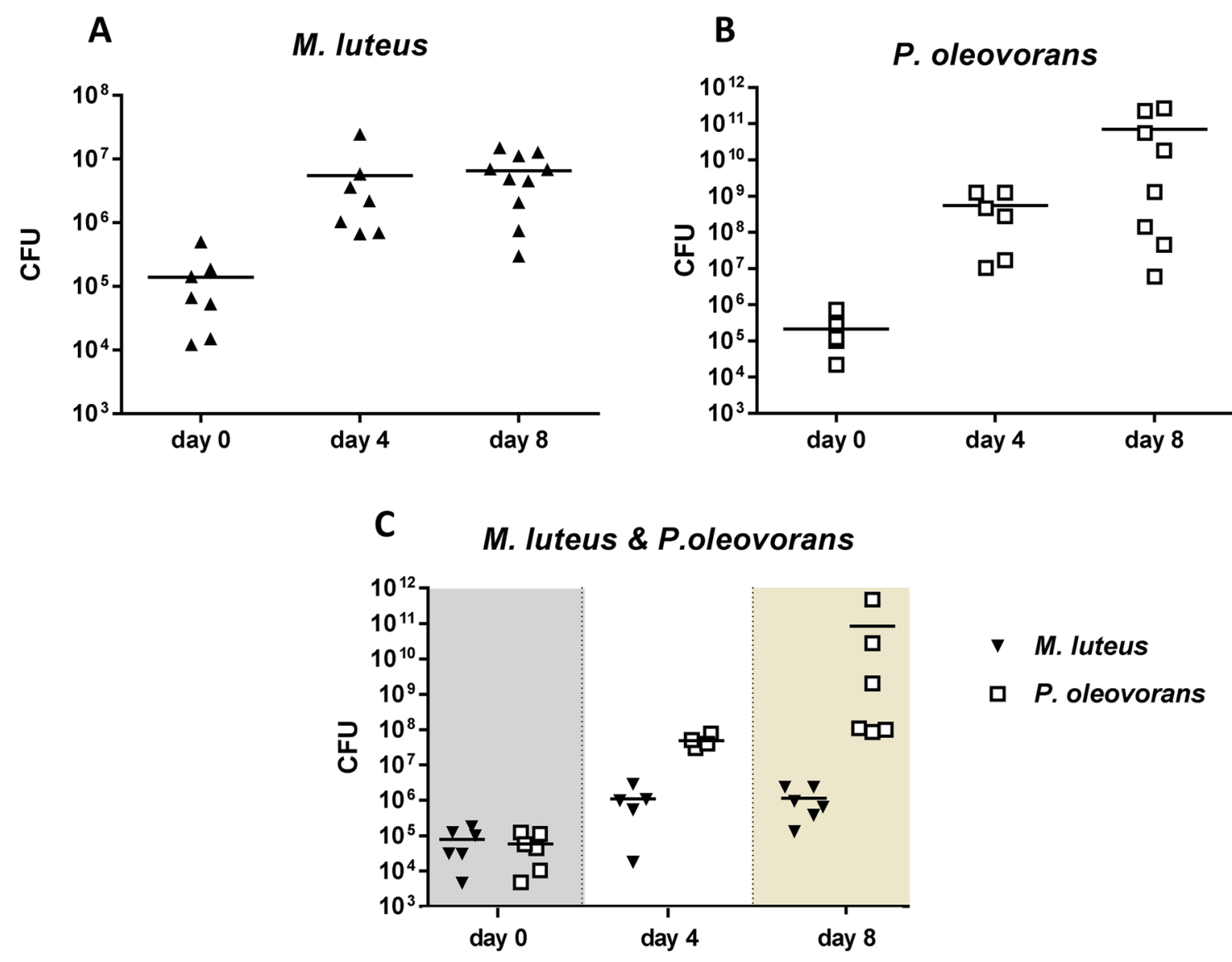

Fig. 1 Plate counts from skin models on day 0, 4 and 8 of bacterial colonisation. The panels depict the results recorded for Micrococcus luteus (a), Pseudomonas oleovorans (b) and the mixed culture (c), respectively. Each point represents an independent experiment with the horizontal bars indicating the corresponding arithmetic mean. $C F U$ colony-forming units $\left(p=6.73 \times 10^{-10}\right)$, indicating some activation of the corresponding molecular pathways.

The co-colonised models generally featured increased transcription of TLR2 with P. oleovorans also inducing TLR6. Expression of TLR3 was repressed though and while the stress- and immune-responsive NF- $\mathrm{KB}$ pathway clearly reacted differently to $M$. luteus or P. oleovorans it nevertheless failed to provide any clear functional response on transcriptional level (Supplementary Fig. S5a).

Taken together the transcriptional responses of the cocolonised models thus indicate a state of increased immune competence. This was further confirmed by the expression patterns of various pro- and anti-inflammatory cytokines including IL1- $\alpha$, IL1- $\beta$, IL-10 and TGF- $\beta$. Again, the observed cytokine patterns showed some strain-specific induction, particularly for P. oleovorans (Fig. 3a). Protein secretion was in line with the gene expression data except for Macrophage migration inhibitory factor (MIF) and Monocyte chemoattractant protein (MCP)-1, both of which were recorded at elevated levels in the presence of $P$. oleovorans but failed to show matching transcriptional induction (Fig. 3a-c). Interestingly, exposure to P. oleovorans also induced partial expression of signalling pathways of triggering receptors expressed on myeloid cells (TREMs) (Supplementary Fig. S5b and c). Amongst other functions these receptors act as important immune modulators and are known to be activated by commensal and pathogenic bacteria (Varanat et al. 2017; Wu et al. 2011). Overall, the transcriptional response of combined pro- and anti-inflammatory effects mirrors the reaction against commensals in vivo (Kubinak and Round 2012; Meisel et al. 2018; Nutsch and Hsieh 2012).

Apart from triggering increased immune competence microbial co-colonisation also had marked transcriptional effects on many genes of the fibroblast growth factor family (FGF2, 4, 5 and 12), the vascular endothelial growth factor family (VFGFA and VFGFC), the transforming growth factor beta family (TGFB1 and TGFBI), and the insulinlike growth factor-binding protein family (IGFBP1, 3, 2 and 5) (Fig. 4a). Again, some of these effects were rather strain specific with $P$. oleovorans tending to produce a more pronounced response. Altogether the transcriptional 


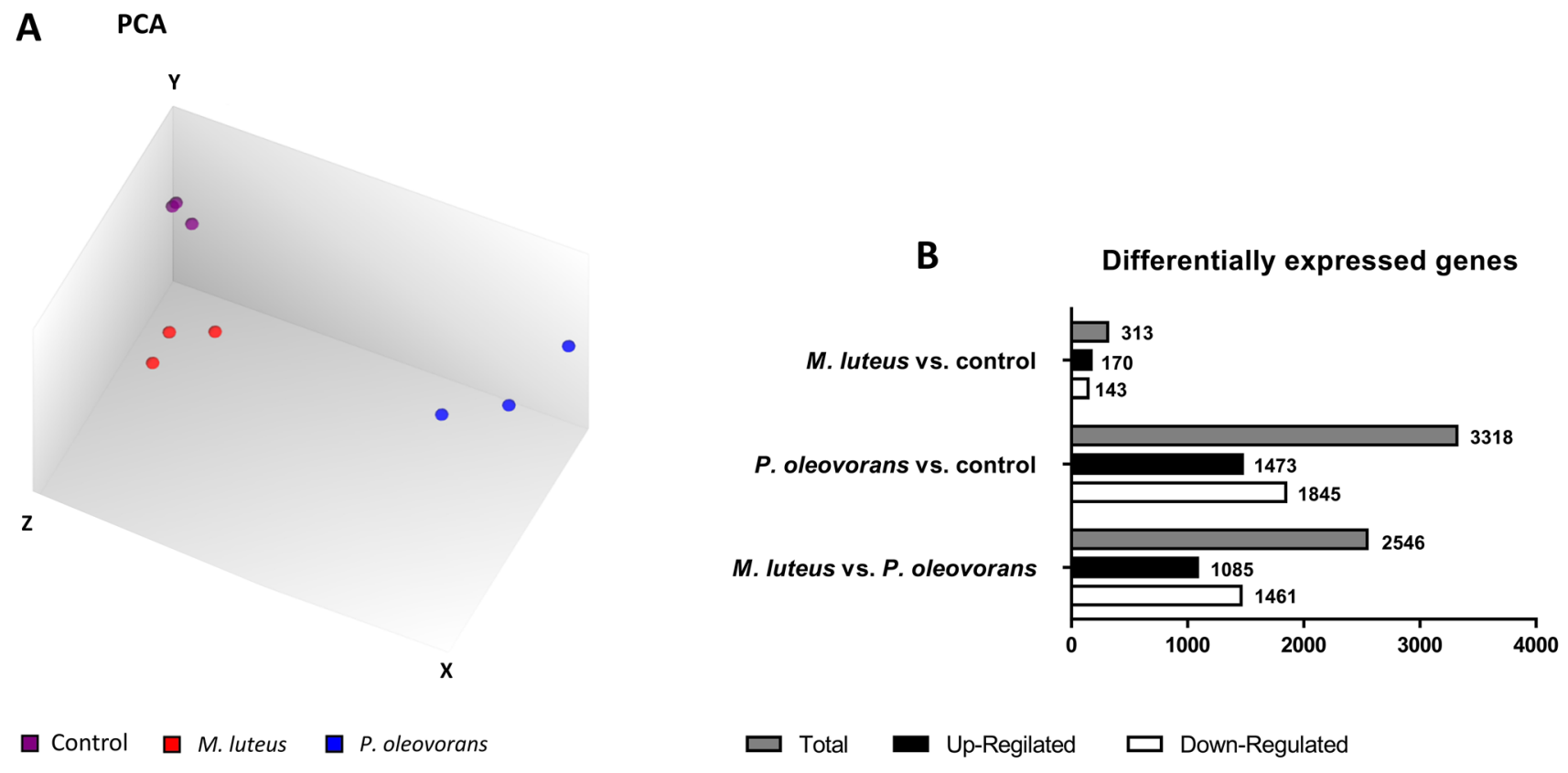

Fig. 2 Transcriptional response of EpiDermFT ${ }^{\mathrm{TM}}$ models on day 8 of microbial colonisation. Mapping $81.4 \%$ of the available transcripts PCA shows clear separation of the untreated control from tissues col- onised with $M$. luteus or P. oleovorans (a). Number of differentially expressed genes in skin colonised with $M$. luteus, $P$. oleovorans and the mixed culture (b). All experiments were conducted in triplicate

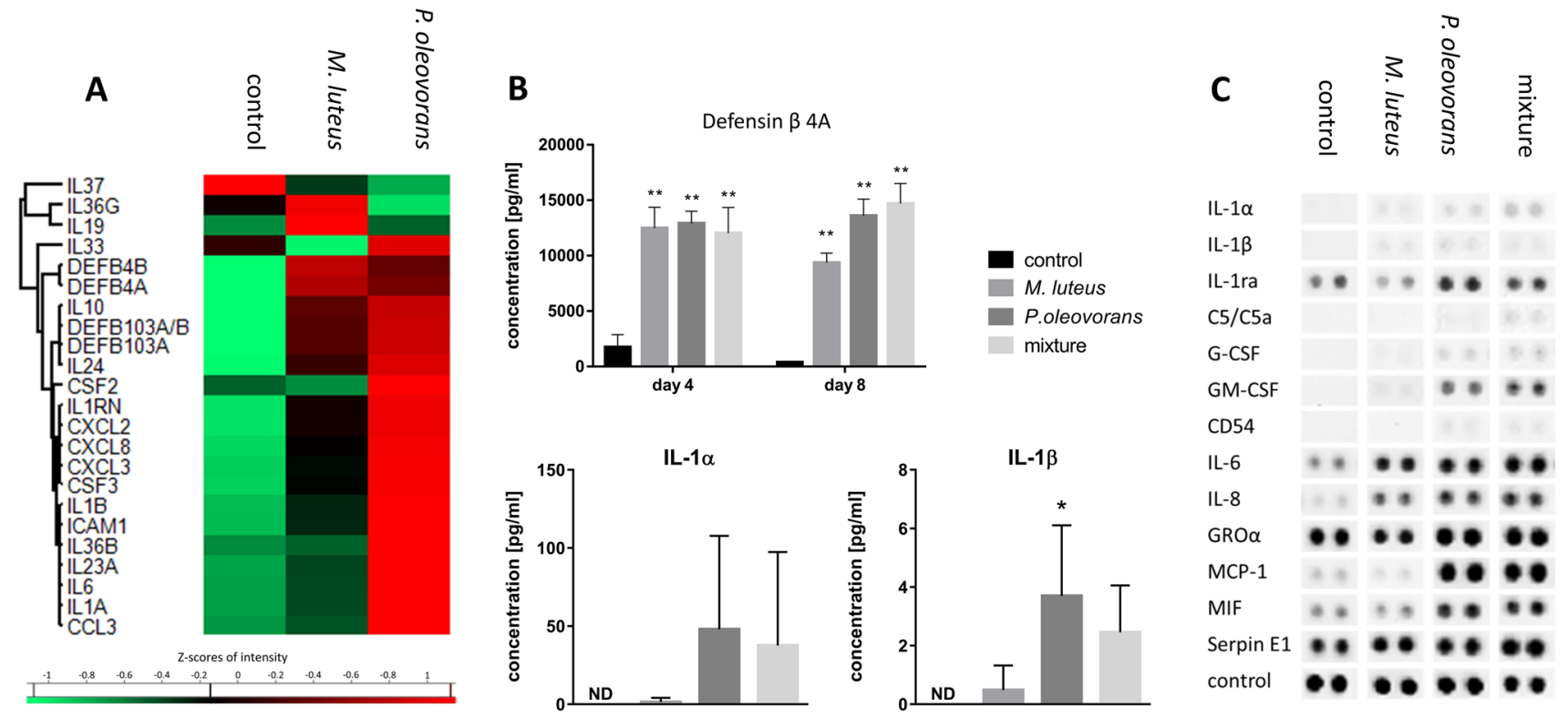

Fig. 3 Expression of various cytokines and defensins in microbially competent skin models. The cluster map records the transcriptional state at day 8 of microbial colonisation as indicated (a). Shown are the gene symbols and Z-scores of significantly differentially expressed genes with an $F$ value $<0.05$ across at least three independent experiments. Concomitant excretion of defensin $\beta 4 \mathrm{~A}$ and IL- $1 \alpha / \beta$

effects seemed to be representative of the model's priming towards more fine-tuned differentiation rather than into the supernatant was quantified using an ELISA and FACS analysis, respectively (b). Shown are mean concentrations with error bars indicating standard deviation. All values are significant within $* p<0.05$ or $* * p<0.01$, values labelled "ND" were not detectable. Similarly, cytokine excretion into the supernatant was verified qualitatively using a proteome profiler array (c)

indicating functional differentiation as such, for effects on protein expression were far less pronounced (Fig. 4b, c). The 


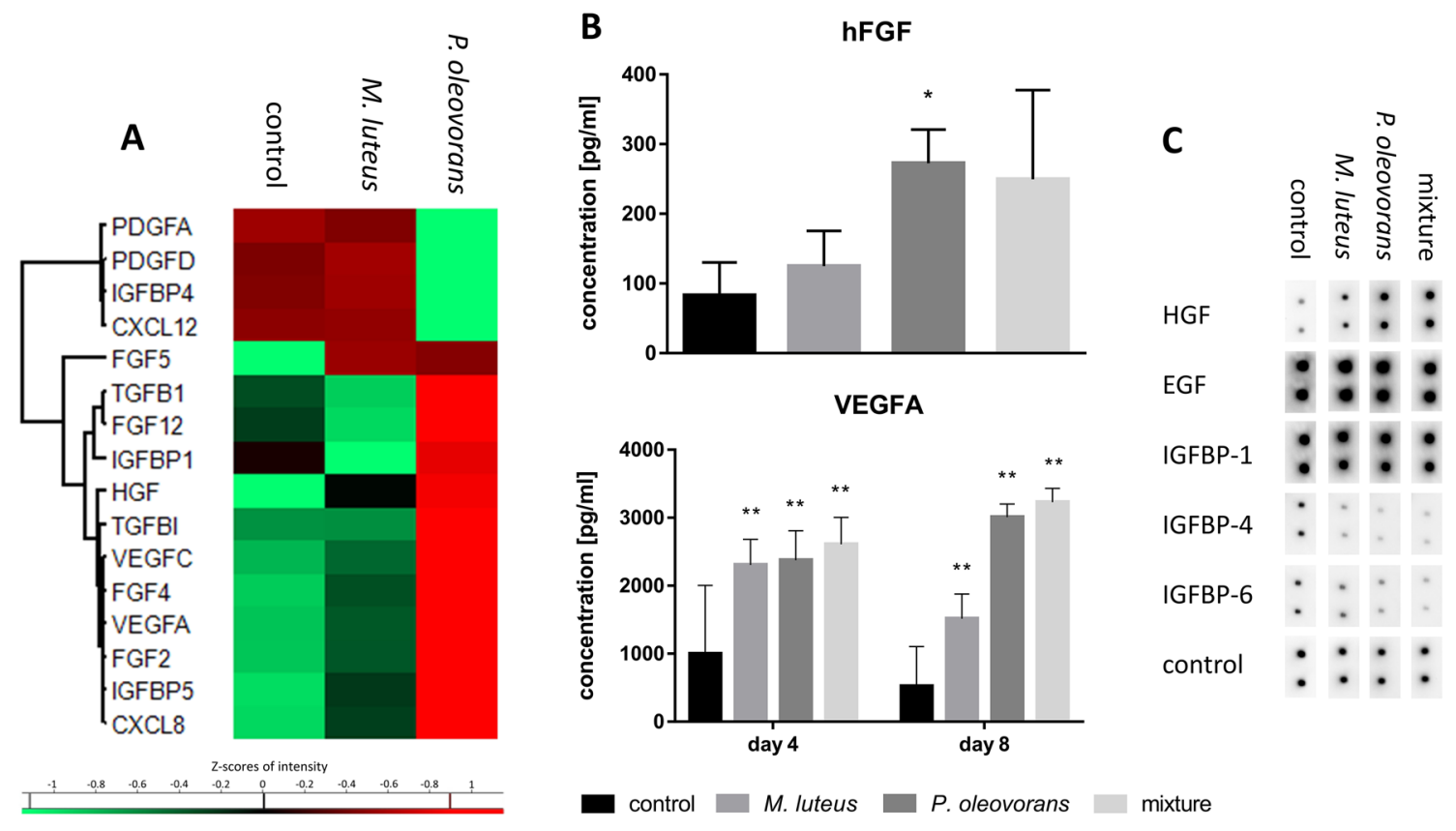

Fig. 4 Expression of cellular growth factors in microbially competent skin models, colonised as indicated. The cluster map records the transcriptional state at day 8 of microbial colonisation (a). Shown are the gene symbols and Z-scores of significantly differentially expressed genes with an $F$ value $<0.05$ across at least three independent experiments. Concomitant excretion of hFGF and VEGFA into the super-

latter only related well for selected transcripts such as the microbially induced expression of VFGFA and hepatocyte growth factor (HGF), or the downregulation of IGFBP6 and IGFBP4, respectively.

Commensal communities are also known to induce strong differential expression of many olfactory receptors (ORs). With about 400 members this receptor family is expressed throughout the body, regulating physiological cell functions well beyond olfaction. In skin this includes keratinocyte proliferation, migration, and re-epithelialisation of keratinocytes (Cheret et al. 2018; Denda 2014). Markedly microbial-skin tissue co-culture with P. oleovorans or M. luteus led to 77 or 15 differentially regulated ORs (Supplementary Fig. S6), with the functional implications remaining unclear though.

\section{Impact on metabolic competence}

In light of the intended use for toxicological studies the colonised skin models were further analysed with respect to transcription of various cytochrome P450-dependent monooxygenases (CYPs), an enzyme class that represent the mainstay in phase I metabolism (Fig. 5a, b). Of the 63 CYPs examined almost $30 \%$ were transcriptionally affected in microbial-skin tissue co-culture, with most of the responses being strain specific to various degrees. However, amongst the six CYPs characteristic for skin metabolism (i.e., CYP1A1, CYP1B1, natant was quantified using an ELISA (b). Shown are mean concentrations with error bars indicating standard deviation. All values are significant within $* p<0.05$ or $* * p<0.01$. Expression of growth factors into the supernatant was further verified qualitatively using a proteome profiler array $(\mathbf{c})$

CYP2B6, CYP2E1, CYP2D6, and CYP3A) only CYP1A1 and CYP2D6 were subject to some additional induction in the presence of $P$. oleovorans, with transcript levels rising 1.7-fold and 2.4-fold compared to the uncolonised control. This trend was also confirmed by quantitative RT-PCR. Taken together the results show that while co-colonisation adds an additional layer of microbial metabolism with potentially biasing effects on the skin's inherent CYP-mediated phase I capacity, its impact is likely to remain moderate.

\section{Discussion}

The human microbiome is an integral part of our (patho) physiology. Yet, an overwhelming part of microbiome research still concentrates on the description of microbial communities and their population dynamics (Round and Palm 2018; Sazal et al. 2020; Walter et al. 2020). Contrastingly and with hardly any in vitro systems available studying the underlying mechanisms and causality of host-microbe interactions remains a major challenge. For the gut Human Microbiota-Associated Mice (HMA) often continue to be a preferred system, despite all technical limitations and ethical issues. With only $15 \%$ of gut bacterial lineages shared compositional differences of the intestinal microbiomes in man and mice far exceed those within species (Ley et al. 


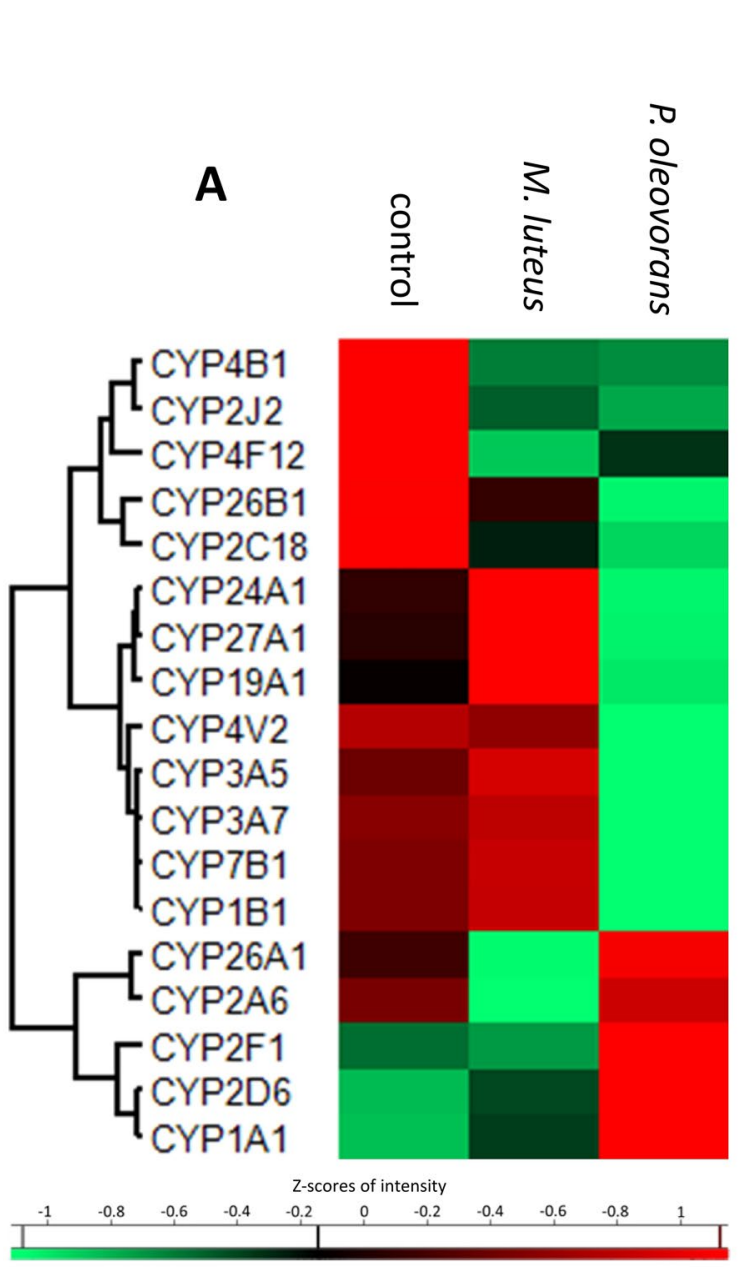

Fig. 5 Expression of various cytochrome P450-dependent monooxygenases (CYPs) involved in phase I metabolism in the skin with the cluster map recording the transcriptional state at day 8 of microbial colonisation (a). Shown are the gene symbols and Z-scores of signifi-

2005) and consequently humanised systems tend to suffer from poor long-term stability (Rawls et al. 2006). Alternatively, bioreactors have hence been used as a simple and effective method to study microbial metabolism and community dynamics under various dietary and xenobiotic influences (Guzman-Rodriguez et al. 2018). Yet, as with other techniques these systems are also subject to limitations such as culturability, long-term stability and lack of direct intestinal interaction (Guzman-Rodriguez et al. 2018; Vrancken et al. 2019). The problem becomes even more evident when moving to commensal communities outside the gut. Rodent skin for example not only features its own species-specific microbiome, but also is profoundly different in terms of physiology and metabolism (Gerber Peter et al. 2014; Oesch et al. 2014).

For toxicological and mechanistic studies of the skin, human 3D skin models have hence long been tools of
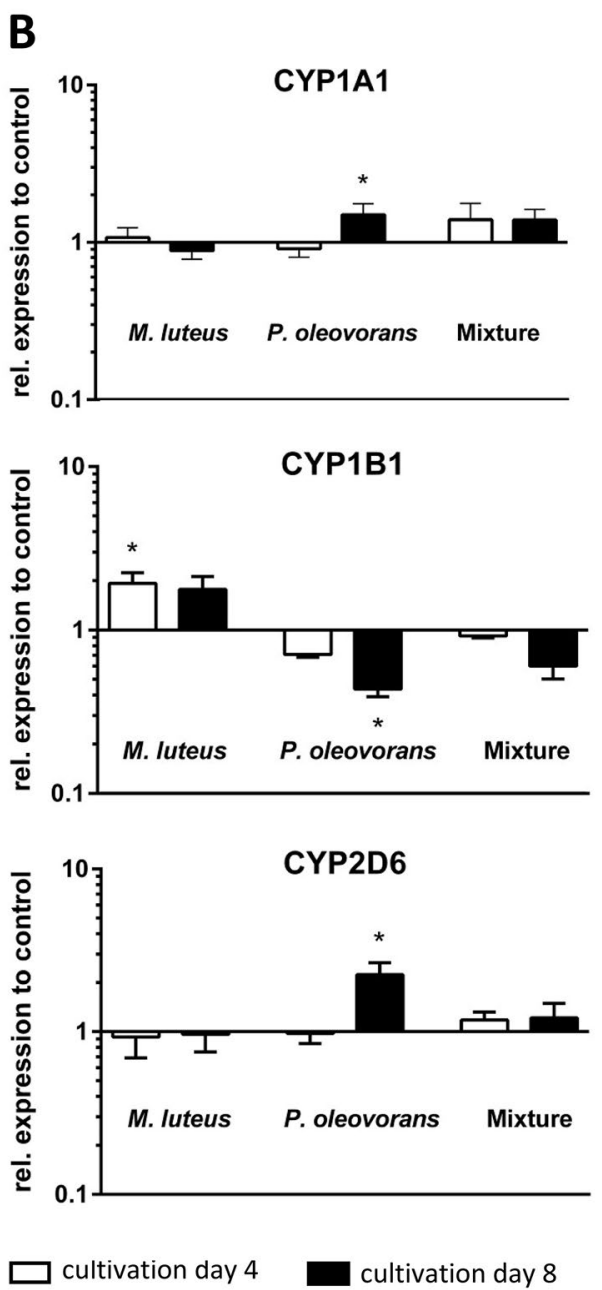

cantly differentially expressed genes with an $F$ value $<0.05$ across at least three independent experiments. Expression of key transcripts was quantified further using RT-PCR (b)

choice, albeit lacking any microbial competence in situ (Rademacher et al. 2018). Systems used to study the pathophysiology of skin-microbe interactions (i.e., during infectious or inflammatory settings) comprise cell cultures with added bacterial endotoxins (Kampfer et al. 2017; Lai et al. 2009), two-dimensional cell cultures in the presence of live pathogens or the odd three-dimensional approach with bacteria added to the culture medium (Barrila et al. 2017; Mason et al. 1998; Mohiti-Asli et al. 2014). Additionally, there is a stratum corneum model from van der Krieken et al. (2016), where bacteria are applied to the apical surface of dead corneocytes or a model from de Breij et al. (2012), where an epidermal skin equivalent is colonised by Acinetobacter species. While the latter models come close to the in vivo situation, at least structurally, they nevertheless lack the option to study microbial interaction with living keratinocytes and fibroblasts. 
There are also studies on colonising 3D skin equivalents which feature dermis, epidermis and a fully differentiated stratum corneum as well as surface contact with ambient air. However, these models have not been pre-validated for toxicity studies. Also, the colonisation in these studies has been limited to $48-120 \mathrm{~h}$. Yet, the studies of Sowada et al. (2017) show that at least for PAHs microbe-mediated toxicity occurs predominantly at time-points later than 5 days. Moreover, the aforementioned models often lack a detailed biochemical characterisation (Bojar 2015; Cadau et al. 2017; Holland et al. 2008; Maboni et al. 2017; Popov et al. 2014).

For our studies we used MatTek's full thickness skin model EpiDermFT ${ }^{\mathrm{TM}}$. Together with fully functional barrier properties and a metabolic complexity close to that of in vivo skin this model has a proven track record as reliable testing system for skin toxicity (Black et al. 2010; Brinkmann et al. 2013; Wills et al. 2016). The successful microbial colonisation reported in this study is a major functional amendment as it provides, to the best of our knowledge, the first testing system for assessing "longer term" skin-microbiome interactions in situ. The skin models were efficiently colonised with commensal communities of $M$. luteus and P. oleovorans, with the letter performing slightly better than the first. Following inoculation microbial-skin tissue co-cultures took up to 4 days to establish and remained stable at least until day 8 with colony counts similar to what is reported for skin in vivo (up to $10^{9} \mathrm{CFU} / \mathrm{cm}^{2}$ ) (Ross et al. 2019; Tralau et al. 2015). In general, P. oleovorans was repeatedly observed to grow to higher cell counts compared to M. luteus both in single and mixed microbial-skin tissue co-culture. For some experiments this resulted in cell counts of up to $10^{11}$ cells $/ \mathrm{cm}^{2}$ for $P$. oleovorans on day 8 . This is possibly due to an increased robustness against nutrient limitation and this organism's ability to colonise not only the stratum corneum but to penetrate into the epidermis and dermis, particularly in absence of a fully functional immune response. This growth behaviour matches that reported for other Pseudomonas spp. in human skin biopsies (Nakatsuji et al. 2013). In contrast, $M$. luteus cell counts were slightly reduced in mixed microbial-skin tissue co-cultures probably due to its dependence on a more restricted range of carbon sources (Young et al. 2010). What is more, is that $3 \mathrm{D}$ skin models such as EpiDermFT ${ }^{\mathrm{TM}}$ do not have sweat glands or hair follicles. This limits the choice of naturally available nutrients to peptides and lipids, restricting access to urea, ammonia, vitamins or sugars (Scharschmidt and Fischbach 2013). However, the latter will at least partially be compensated for by diffusion of glucose from the cell culture medium into the dermal and epidermal layers of the model (Khalil et al. 2006; Ullah et al. 2018). This provides some selectional advantage for the more invasive
P. oleovorans as even a thin stratum corneum layer constitutes a considerable barrier for passive diffusion (Ullah et al. 2018).

Transcriptional influence of the skin microbiome on its host is well established, although little understood and thus of high interest (Duckney et al. 2013; Linehan et al. 2018; Ridaura et al. 2018; Wanke et al. 2011). The extent and impact are community specific, something also seen in our models where $P$. oleovorans influenced the transcription of nearly 3300 genes. That is nearly tenfold the number of transcripts affected by M. luteus and in the same order of magnitude what is seen in germ-free mice in response to microbial colonisation (Meisel et al. 2018). Part of this gene response is likely to be the consequence of $P$. oleovorans penetrating the epidermal barrier and its relatively high cell count of up to $10^{11} \mathrm{CFU} / \mathrm{cm}^{2}$ on the eighth day of cultivation. With $P$. oleovorans being an opportunistic pathogen an immunogenic response is inherently necessary to maintain a healthy commensal community. Duckney et al. (2013) reported a strong and predominantly inflammatory response in skin models when mimicking complete barrier breakdown. The effects observed in our colonised models are less acute and rather in line with what is seen for commensal communities in vivo. For example, similar to what is seen in host-microbiome animal studies both organisms lead to increased gene expression of $\beta$-defensins DEFB3A and DEFB4A (Lai et al. 2010; Rademacher et al. 2019). These $\beta$-defensins are critical but not exclusive for host defence, with induction of DEFB3A relying, amongst other things, on activation of TLR2 (Shin and Choi 2010). Befittingly we also see increased levels of $T L R 2$ expression in the skin subsequent to microbial colonisation. The increase was significantly more pronounced in skin models colonised with P. oleovorans, together with a slight but significant upregulation of TLR 6. Induction of TLR2 by LPS from Pseudomonas species has been shown earlier (Shin et al. 2013). Homo- or heterodimers of TLR2 or TLR2/TLR6 are capable of discriminating various lipopeptides (Takai et al. 2014) and are involved in immune modulation, including elicitation of cytokine secretion and promotion of regulatory T (Treg) cell (Nawijn et al. 2013; Netea et al. 2008; van Maren et al. 2008) and Th17 cell responses (DePaolo et al. 2012; Reynolds et al. 2010; Xu et al. 2017; Zhao et al. 2015). Results from preliminary screens with THP-1 cells further support this as exposure to medium from microbially competent models leads to secretion of IL-23, a cytokine crucial for Th17 development and adaptive immunity (Supplementary Fig. S7) (McGeachy et al. 2009; Zielinski et al. 2012). Various TLRs have been implicated to modulate the immune responses to commensals in vitro (Kubinak and Round 2012; Maier et al. 2018; Ren et al. 2016) as well as in vivo (Oppong et al. 2013; Round et al. 2011), often promoting mutually beneficial microbe-host interactions. Amongst the respective target cytokines are 
IL-1 $\alpha$, IL-1 $\beta$, IL-6 (Hasegawa et al. 2012; Naik et al. 2012; Ren et al. 2016) and IL-10 (Cosseau et al. 2008; Jun et al. 2017; Neish 2009), all of which we found to be elevated in the presence of P. oleovorans and M. luteus. The transcription of these cytokines is partly subject to TREM-1 signalling, which was significantly induced in models colonised with P. oleovorans (Lagler et al. 2009; Rai and Agrawal 2017; Tessarz and Cerwenka 2008). Commensalic influence on IL-1 signalling is known to modulate effector T cell responses. The corresponding modulation and fine-tuning of immune responses is essential for a functioning host-microbiome relationship as well as for maintaining a healthy skin (Naik et al. 2012; Park and Lee 2017). In fact, maturation of IL- $1 \alpha$ and IL- $1 \beta$ crucially depends on commensal presence (Lopez-Castejon and Brough 2011; Naik et al. 2012). Indeed microbial-skin tissue co-cultures with both organisms showed an increase in gene expression and excretion for both cytokines. Other genes of the interleukin- 1 family were also upregulated, including IL-33 and IL-36 $\beta$ for $P$. oleovorans and IL-36y for M. luteus. Similarly the observed expression of anti-inflammatory messengers such as IL-10 and TGF- $\beta$ has been linked to commensal colonisation and associated immune tolerance (Fung et al. 2016; Meisel et al. 2018; Ueda et al. 2010). Altogether the response of the co-colonised models thus is very much similar to what is observed in vivo, with increased immunomodulation and immunotolerance, respectively (Nutsch and Hsieh 2012). Similarly, many of the aforementioned transcription factors and genes found to be transcriptionally affected by co-colonisation match those seen in skin development and differentiation in vivo. Examples include the host angiogenesis transcription factor Ephrin-A1 as well as the growth factors FGF2, HGF, PTGER4, VEGFA and VEGFC or ORs such as OR2A7 (Linehan et al. 2018; Sajib et al. 2018; Stappenbeck et al. 2002). The latter is known to play an important role in various processes of the skin, including keratinocyte proliferation (Tsai et al. 2017). The regulation of ORs by human commensals has so far been little studied. Pluznick et al. (2013) showed critical involvement of OR51E2 in intestinal host-microbiome signalling. In our skin models this receptor was upregulated in the presence of $P$. oleovorans. Interestingly, seven of the genes from the OR family were differentially regulated in both microbial-skin tissue co-cultures. Continuatively, it seems worthwhile to assess the general role of ORs in skin-microbiome signalling in more detail.

Colonisation of the skin models also had a marked influence on CYP expression with almost $30 \%$ of CYPs affected, including the toxicologically relevant CYP1A1. In mice CYP1A1-facilitated detoxification of carcinogens has been implicated to rely on TLR2-dependent signalling (Do et al. 2012). Therefore, the differential expression of TLR2 with P. oleovorans is likely also causal for this organism's marked induction of CYP1A1. While little is known for skin, the overall microbial influence on CYP expression in the gut has been reported previously. This includes CYP3A, CYP2C9, CYP1A and CYP2D6, for which microbial metabolites can either serve as substrates, inductors or inhibitors (Claus et al. 2011; Tralau et al. 2015). Biological pathway analysis also implicated microbial influence of both organisms on other key processes such as proliferation, keratinocyte differentiation and apoptosis. In general, P. oleovorans seems to have a greater influence on processes pertained to cellular movement of the dermis (fibroblasts and connective tissue), whereas M. luteus rather influences keratinocyte movement. This is probably due to the different habitats of the organisms. So far, little is known about the influence of microorganisms on cell proliferation and differentiation in the skin. However, our results confirm that the balance between epidermal proliferation and differentiation is altered in response to microbial colonisation (Meisel et al. 2018). The underlying pathways involve signalling of MAPK and NF- $\mathrm{KB}$ as well as IL-1 and DEFB3/4A, all of which we found to be affected (Eller et al. 1995; Nishimura et al. 2004; Preciado et al. 2005).

Currently, the model is limited to a selected number of species as it has not been tested for entire swabs or community stamps. As such it will also always be limited to the cultivation bias inherited by all growth-based models. This is not the least because it carries the inherent limitations of MatTek's EpiDermFT ${ }^{\mathrm{TM}}$ such as the absence of sweat glands and selections glands, both of which contribute to the nutrient pool of natural skin communities. However, the microbially mediated changes in the skin matched what is known from other skin studies and mouse models. This is true for the observed alterations in gene expression such as the IL-1 family, the secretion of antimicrobial peptides and the predicted influence on skin differentiation and proliferation. As an extendable microbial-skin tissue co-culture system this model hence provides a good system for studying selected skin host-microbiome interactions including microbiome-mediated substance toxification in situ over extended periods of time.

\section{Materials and methods}

\section{Chemicals and media}

If not mentioned otherwise chemicals were purchased at purities greater than 98\% from Sigma-Aldrich (Taufkirchen, Germany) or Carl Roth (Karlsruhe, Germany), respectively. Media for the 3D skin models were sourced from MatTek (Ashland, MA) while molecular reagents and kits were routinely obtained from Qiagen (Hilden, Germany) and Invitek (STRATEC Molecular GmbH, Berlin, Germany). Primers were purchased from Metabion (Martinsried, Germany). 


\section{Bacterial isolates and bacterial growth}

Microbial-skin tissue co-cultures were set up using two previously enriched skin-commensals, that is Micrococcus luteus 1B and Pseudomonas oleovorans 1C (Sowada et al. 2014). When not applied on the surface of the skin models bacteria were routinely grown as shake flask cultures in lysogeny broth (LB) at $200 \mathrm{rpm}$ and $32{ }^{\circ} \mathrm{C}$. Growth was routinely monitored using optical density (OD, $\lambda=600 \mathrm{~nm}$ ) and correlated to colony-forming units (CFU) as established by serial plate counts (PC) as required. Cells used for skin model inoculation were harvested at an $\mathrm{OD}_{600}$ of $0.4-0.9$ with $7.500 \mathrm{~g}$ for $8 \mathrm{~min}$ and washed once in PBS (MatTek, Ashland, MA, USA). The pellet was subsequently re-dissolved in $15 \mu \mathrm{PBS}$ and $10^{4}-10^{6}$ cells used for skin inoculation.

\section{Whole-genome sequencing (WGS)}

For each isolate a single colony grown on LB agar was inoculated in liquid LB and cultivated under shaking conditions at $150 \mathrm{rpm}$ and $37^{\circ} \mathrm{C}$ for $22 \pm 2 \mathrm{~h}$. Subsequent extraction of DNA was performed using the PureLink ${ }^{\circledR}$ Genomic DNA Mini Kit (Invitrogen, Carlsbad, CA, USA). Sequencing libraries were then prepared with the Nextera XT DNA Sample Preparation Kit (Illumina, San Diego, CA, USA) according to the manufacturer's protocol. Paired-end sequencing performed in $2 \times 301$ cycles on an Illumina MiSeq benchtop using the MiSeq Reagent v3 600-cycle Kit (Illumina).

\section{Tissue culture}

Skin models (EpiDermFT ${ }^{\mathrm{TM}}$ ) were obtained from MatTek (Ashland, MA, USA). Three days before shipment the models are started to cultivated in antibiotic-free medium. Upon arrival the models were directly transferred into sixwell plates (Greiner Bio-One, Frickenhausen, Germany) and allowed to recover overnight in $2.5 \mathrm{ml}$ of antibiotic-free EPI-100-MM-ABF at $37{ }^{\circ} \mathrm{C}$ and $5 \% \mathrm{CO}_{2}$ as recommended by the manufacturer. Following recovery the models were then subjected to bacterial inoculation or solvent treatment, respectively. Models were subsequently maintained at $37{ }^{\circ} \mathrm{C}$ in a humidified atmosphere of $5 \% \mathrm{CO}_{2}$ for up to 8 days with culture media being exchanged daily, following the recommendations of the manufacturer who warrants culture stability for up to 2 weeks. Tissues and media not used upon completion were harvested, shock-frozen in liquid $\mathrm{N}_{2}$ and stored at $-80{ }^{\circ} \mathrm{C}$ as appropriate. Model sections to be used for bacterial staining were transferred into embedding medium prior to freezing.

The medium of microbial-skin tissue co-culture models was checked daily for contamination by sampling for possible bacterial growth by $\mathrm{OD}_{600}$-measurements and plating.
Follow-up experiments were only carried out if the medium was free of contamination.

Please note that it is highly recommended to use different plates for different microbial-skin tissue co-cultures. This minimises the risk of cross-contamination. Also, the volume of the bacterial inoculum applied topically should not exceed $15 \mu \mathrm{l}$.

\section{Bacterial quantification: skin models}

Bacterial growth in microbial-skin tissue co-culture was quantified using PC or strain-specific quantitative PCR (ss-qPCR) (as described in the supplementary section Method S1), respectively. For the PC bacterial imprints were obtained from the surface of the skin models using $2 \mathrm{~cm}^{2}$ of velvet cloth. The cloth was soaked in sterile PBS and applied with gentle pressure to the surface of the skin model before being subsequently transferred into $1 \mathrm{ml}$ of sterile PBS. Following incubation in a thermomixer (Eppendorf, Hamburg, Germany) at room temperature for $30 \mathrm{~min}$ at $6000 \mathrm{rpm}$ the velvet was wrung out and $100 \mu \mathrm{l}$ of the bacterial PBS-suspension were used to set up serial dilutions on LB agar. After $24 \mathrm{~h}$ at $37{ }^{\circ} \mathrm{C}$ bacterial counts were then recorded as $\mathrm{CFU} / \mathrm{ml}$.

In order to preclude the possibility of a contamination with other microorganisms, we have performed a PCR with 16S-rRNA gene-specific primers (Tralau et al. 2011) with the DNA of the individual models, followed by sequencing of the PCR products at Eurofins (Ebersberg, Germany).

\section{Bacterial staining of co-colonised skin models}

For bacterial stains frozen model sections $\left(\sim 1 \mathrm{~cm}^{2}\right)$ were cut in a cryomicrotome at $-20{ }^{\circ} \mathrm{C}$. Slices were set to measure $5 \mu \mathrm{m}$ in diameter and then subjected to standard Gram-staining using the Gram stain tissue kit (Sigma, St. Louis, MO, USA). Staining was performed according to the manufacturer's instructions relying on precooled acetone $\left(-20^{\circ} \mathrm{C}\right.$, $20 \mathrm{~min}$ ) as fixation agent. The results were recorded using a standard Axio Observer A1 microscope (Zeiss, Oberkochen, Germany).

\section{THP-1 cell culture}

THP-1 cells were obtained from Leibniz Institute DSMZGerman Collection of Microorganisms and Cell Cultures (Braunschweig, Germany). Growth was routinely performed using RPMI 1640 medium (PAN-Biotec, Aidenbach, Germany) supplemented with 10\% (v/v) FBS (Biochrom, Berlin, Germany), HEPES; $10 \mathrm{mM}$, L-glutamine $(2 \mathrm{mM})$, sodium pyruvate $(1 \mathrm{mM})$ and penicillin/streptomycin $(100 \mathrm{U} / \mathrm{ml})$ (PAN-Biotec). For routine cell culture 
cells were seeded at $1 \times 10^{5}$ cells per ml into T75 flasks at $37{ }^{\circ} \mathrm{C}, 5 \% \mathrm{CO}_{2}$ and $95 \%$ humidity and passaged every 3-4 days.

Cells used for cytokine arrays were seeded into 96-well plates at a density of $0.5 \times 10^{6}$ cells per 96 well plate and left to rest for $24 \mathrm{~h}$ before being subjected to treatment with supernatants from the respective skin models for another $24 \mathrm{~h}$.

\section{mRNA analysis}

Total RNA was recovered subsequent to cell harvesting with a TissueLyser II (Qiagen, Hilden, Germany) using a TRIzol-based protocol (Chomczynski and Sacchi 1987). Briefly, following cellular disruption at $20 \mathrm{~Hz}$ for $3 \mathrm{~min}$, total RNA was extracted using TRIzol ${ }^{\mathrm{TM}}$ Reagent (Invitrogen) according to the manufacturer's instructions. The RNA-integrity (RIN) was analysed with an Agilent 2100 Bioanalyzer System (Agilent Technologies, Waldbronn, Germany) and the Agilent RNA 6000 Nano Kit (Agilent Technologies, Waldbronn, Germany) as described by the manufacturer. Following quality assessment samples were either stored at $-80{ }^{\circ} \mathrm{C}$ or directly used for quantitative RT-PCR or microarray analysis, respectively.

Microarray analysis was performed using triplicate Human Clariom ${ }^{\mathrm{TM}} \mathrm{S}$ assays (Applied Biosystems, Foster City, CA, USA) at ATLAS Biolabs (Berlin, Germany). The corresponding RNA-samples all featured a RIN-score $>7$. Subsequent data evaluation and interpretation was then carried out in house, relying on the Transcriptome Analysis Console 4.0.1.36 (TAC) (Applied Biosystems, Foster City, CA, USA) ( \pm 2 fold-change; $p<0.05$ ) and Ingenuity Pathway Analysis (IPA) (QIAGEN Inc., https://www. qiagenbioinformatics.com/ products/ingenuity-pathwayanalysis, Qiagen, Hilden, Germany) software packages. The latter was used with its core analysis module using \pm 1.5 -fold-change and $p<0.05$ as cut-off values.

Concomitant analysis of gene-specific expression was performed using quantitative RT-PCR. In brief $500 \mathrm{ng}$ of mRNA were reversely transcribed using oligo-dT primers and the Omniscript ${ }^{\circledR}$ Reverse Transcription Kit (Qiagen, Hilden, Germany). Subsequent amplification and detection of transcript levels relied on gene-specific primers (Supplementary Table S2) together with Fast SYBR ${ }^{\circledR}$ Green Master Mix (Applied Biosystems, Thermo Fisher Scientific, Darmstadt, Germany) as instructed by the manufacturer. All experiments were carried out in triplicate with $G A P D H$ as house-keeping control and using a 7500 Fast Real-time cycler by Applied Biosystems (Thermo Fisher Scientific, Darmstadt, Germany). Relative transcript levels were calculated based on $c_{\mathrm{T}}$-values using the 7500 Fast SDS Software.

\section{Quantification of secreted factors}

Cytokine secretion of microbially competent skin and THP-1 cells was measured using a Proteome Profiler ${ }^{\mathrm{TM}}$ Human Cytokine Array Panel A (R\&R Systems, Abingdon, UK). Il- $1 \alpha$ and $\beta$ were additionally quantified in microbial-skin tissue co-culture using a custom human 7-plex panel (Biolegend, London, UK) and FACS. Growth factor secretion was measured using the Human Growth Factor Array C1 (RayBiotech, Peachtree Corners, GA, USA). Levels of VEGFA and Defensin $\beta 4 \mathrm{~A}$ or hFGF were determined with ELISA kits from RayBiotech, Inc. (Norcross, GA, USA) or USCN Life Science (Wuhan, China) according to the manufacturer's protocol, respectively.

\section{Western blot}

Expression of selected proteins in skin models was verified using Western blotting. For protein extraction skin tissues in PBS $(250 \mu \mathrm{l})$ were lysed with a TissueLyser II (Qiagen, Hilden, Germany) operated for $5 \mathrm{~min}$ at $20 \mathrm{~Hz}$ in in presence of Protease Inhibitor Cocktail Set III ( $3 \mu$ l, Merck, Darmstadt, Germany). Extracts equivalent to $30 \mu \mathrm{g}$ of total protein were then subjected SDS-PAGE and transferred to nitrocellulose membranes following standard protocols. Primary antibodies against TREM-1 (sc-293450), DAP12 (sc-166084) and GAPDH (ab-9485) were used (Santa Cruz Biotechnology, Santa Cruz, CA, USA; Abcam, Cambridge, Great Britain) for subsequent immunostaining, followed by visualisation with appropriate horseradish peroxidase-coupled secondary antibodies (Santa Cruz Biotechnology) and enhanced chemo-luminescence (34078; Thermo Scientific, Waltham, MA, USA) for detection.

\section{Statistical analysis}

All experiments were performed with at least three biological replicates. Data are presented as mean \pm SD. GraphPad Prism 6 (Statcon, Witzenhausen, Germany) was used for statistical data processing with analyses of multiple groups by one-way ANOVA with Dunnett's multiple comparisons test or ordinary two-way ANOVA being performed as appropriate. All results are statistically significant within $p<0.05$ unless stated otherwise.

Acknowledgements Open Access funding provided by Projekt DEAL. The authors acknowledge intramural funding at the German Federal Institute for Risk Assessment (BfR). Equally acknowledged is the experimental and technical assistance of Nils Dommershausen, Julian Tharman, Jane Kowall and Thomas Fischer.

Author contributions TT and LL conceived and designed the experiments. LL performed the sampling, experimental work and analysed 
the data. SAD, RD and SV performed the genome sequencing and established the qPCR for bacterial quantification. AL provided conceptual input. LL, TT and AL wrote the manuscript with all authors approving the final version.

Funding This work was supported by Federal Institute for Risk Assessment Grant 1322-656.

Availability of data and material Raw and processed data files are deposited in the Gene Expression Omnibus (GEO) data repository GSE98877 Super Series upon publication.

\section{Compliance with ethical standards}

Conflict of interest The authors declare that they have no competing interests.

Ethics approval Their suppliers have represented in writing that they are strictly regulated by and comply with German federal government standards.

Consent to participate Skin models as obtained from MatTek rely on ethically sourced materials from accredited institutes and are subject to strict donor consent.

Open Access This article is licensed under a Creative Commons Attribution 4.0 International License, which permits use, sharing, adaptation, distribution and reproduction in any medium or format, as long as you give appropriate credit to the original author(s) and the source, provide a link to the Creative Commons licence, and indicate if changes were made. The images or other third party material in this article are included in the article's Creative Commons licence, unless indicated otherwise in a credit line to the material. If material is not included in the article's Creative Commons licence and your intended use is not permitted by statutory regulation or exceeds the permitted use, you will need to obtain permission directly from the copyright holder. To view a copy of this licence, visit http://creativecommons.org/licenses/by/4.0/.

\section{References}

Barrila J, Yang J, Crabbe A et al (2017) Three-dimensional organotypic co-culture model of intestinal epithelial cells and macrophages to study Salmonella enterica colonization patterns. NPJ Microgravity 3:10. https://doi.org/10.1038/s41526-017-0011-2

Barton GM, Medzhitov R (2003) Toll-like receptor signaling pathways. Science 300(5625):1524-1525. https://doi.org/10.1126/ science. 1085536

Berry D, Loy A (2018) Stable-isotope probing of human and animal microbiome function. Trends Microbiol 26(12):999-1007. https ://doi.org/10.1016/j.tim.2018.06.004

Black AT, Hayden PJ, Casillas RP et al (2010) Expression of proliferative and inflammatory markers in a full-thickness human skin equivalent following exposure to the model sulfur mustard vesicant, 2-chloroethyl ethyl sulfide. Toxicol Appl Pharmacol 249(2):178-187. https://doi.org/10.1016/j.taap.2010.09.005

Bojar RA (2015) Studying the human skin microbiome using 3D in vitro skin models. Appl In Vitro Toxicol 1(2):165-171. https ://doi.org/10.1089/aivt.2015.0002

Brinkmann J, Stolpmann K, Trappe S et al (2013) Metabolically competent human skin models: activation and genotoxicity of benzo[a]pyrene. Toxicol Sci 131(2):351-359. https://doi. org/10.1093/toxsci/kfs316

Cadau S, Valla-Dury L, Cenizo V et al (2017) Studying microbiote competition and skin interaction using organotypic 3D skin models. Adv Tissue Eng Regen Med Open Access 2(5):00041. https ://doi.org/10.15406/atroa.2017.02.00041

Cheret J, Bertolini M, Ponce L et al (2018) Olfactory receptor OR2AT4 regulates human hair growth. Nat Commun 9(1):3624. https:// doi.org/10.1038/s41467-018-05973-0

Chiller K, Selkin BA, Murakawa GJ (2001) Skin microflora and bacterial infections of the skin. J Investig Dermatol Symp Proc 6(3):170-174. https://doi.org/10.1046/j.0022-202x.2001.00043.x

Chomczynski P, Sacchi N (1987) Single-step method of RNA isolation by acid guanidinium thiocyanate-phenol-chloroform extraction. Anal Biochem 162(1):156-159. https://doi.org/10.1006/ abio.1987.9999

Christensen GJ, Bruggemann H (2014) Bacterial skin commensals and their role as host guardians. Benef Microbes 5(2):201-215. https ://doi.org/10.3920/BM2012.0062

Claus SP, Ellero SL, Berger B et al (2011) Colonization-induced hostgut microbial metabolic interaction. mBio 2(2):e00271-10. https ://doi.org/10.1128/mBio.00271-10

Clayton TA, Baker D, Lindon JC, Everett JR, Nicholson JK (2009) Pharmacometabonomic identification of a significant host-microbiome metabolic interaction affecting human drug metabolism. Proc Natl Acad Sci USA 106(34):14728-14733. https://doi. org/10.1073/pnas.0904489106

Clemente JC, Ursell LK, Parfrey LW, Knight R (2012) The impact of the gut microbiota on human health: an integrative view. Cell 148(6):1258-1270. https://doi.org/10.1016/j.cell.2012.01.035

Collins SL, Patterson AD (2020) The gut microbiome: an orchestrator of xenobiotic metabolism. Acta Pharm Sin B 10(1):19-32. https ://doi.org/10.1016/j.apsb.2019.12.001

Cosseau C, Devine DA, Dullaghan E et al (2008) The commensal Streptococcus salivarius K12 downregulates the innate immune responses of human epithelial cells and promotes host-microbe homeostasis. Infect Immun 76(9):4163-4175. https://doi. org/10.1128/IAI.00188-08

Davis CP (1996) Medical microbiology: general concepts study guide, 4th edn. University of Texas Medical Branch at Galveston, Galveston

de Breij A, Haisma EM, Rietveld M et al (2012) Three-dimensional human skin equivalent as a tool to study Acinetobacter baumannii colonization. Antimicrob Agents Chemother 56(5):24592464. https://doi.org/10.1128/AAC.05975-11

Denda M (2014) Newly discovered olfactory receptors in epidermal keratinocytes are associated with proliferation, migration, and re-epithelialization of keratinocytes. J Investig Dermatol 134(11):2677-2679. https://doi.org/10.1038/jid.2014.229

DePaolo RW, Kamdar K, Khakpour S, Sugiura Y, Wang W, Jabri B (2012) A specific role for TLR1 in protective $\mathrm{T}(\mathrm{H}) 17$ immunity during mucosal infection. J Exp Med 209(8):1437-1444. https ://doi.org/10.1084/jem.20112339

Do KN, Fink LN, Jensen TE, Gautier L, Parlesak A (2012) TLR2 controls intestinal carcinogen detoxication by CYP1A1. PLoS One 7(3):e32309. https://doi.org/10.1371/journal.pone.0032309

Duckney P, Wong HK, Serrano J, Yaradou D, Oddos T, Stamatas GN (2013) The role of the skin barrier in modulating the effects of common skin microbial species on the inflammation, differentiation and proliferation status of epidermal keratinocytes. BMC Res Notes 6:474. https://doi.org/10.1186/1756-0500-6-474

Dunne A, O'Neill LA (2003) The interleukin-1 receptor/Toll-like receptor superfamily: signal transduction during inflammation and host defense. Sci STKE 2003(171):re3. https://doi. org/10.1126/stke.2003.171.re3 
Egea TC, da Silva R, Boscolo M et al (2017) Diuron degradation by bacteria from soil of sugarcane crops. Heliyon 3(12):e00471. https://doi.org/10.1016/j.heliyon.2017.e00471

Eller MS, Yaar M, Ostrom K, Harkness DD, Gilchrest BA (1995) A role for interleukin-1 in epidermal differentiation: regulation by expression of functional versus decoy receptors. J Cell Sci 108(8):2741-2746

Epstein E (2015) Disposal and management of solid waste: pathogens and diseases. Taylor \& Francis Group, Boca Raton

Feehley T, Nagler CR (2014) Cellular and molecular pathways through which commensal bacteria modulate sensitization to dietary antigens. Curr Opin Immunol 31:79-86. https://doi.org/10.1016/j. coi.2014.10.001

Fung TC, Bessman NJ, Hepworth MR et al (2016) Lymphoid-tissueresident commensal bacteria promote members of the IL-10 cytokine family to establish mutualism. Immunity 44(3):634 646. https://doi.org/10.1016/j.immuni.2016.02.019

Gallo RL, Hooper LV (2012) Epithelial antimicrobial defence of the skin and intestine. Nat Rev Immunol 12(7):503-516. https:// doi.org/10.1038/nri3228

Gerber Peter A, Buhren Bettina A, Schrumpf H, Homey B, Zlotnik A, Hevezi P (2014) The top skin-associated genes: a comparative analysis of human and mouse skin transcriptomes. Biol Chem 395:577

Grice EA, Kong HH, Renaud G et al (2008) A diversity profile of the human skin microbiota. Genome Res 18(7):1043-1050. https ://doi.org/10.1101/gr.075549.107

Grice EA, Kong HH, Conlan S et al (2009) Topographical and temporal diversity of the human skin microbiome. Science (New York, NY) 324(5931):1190-1192. https://doi.org/10.1126/ science. 1171700

Guzman-Rodriguez M, McDonald JAK, Hyde R et al (2018) Using bioreactors to study the effects of drugs on the human microbiota. Methods 149:31-41. https://doi.org/10.1016/j.ymeth .2018 .08 .003

Hanafy RA, Couger MB, Baker K et al (2016) Draft genome sequence of Micrococcus luteus strain O'Kane implicates metabolic versatility and the potential to degrade polyhydroxybutyrates. Genom Data 9:148-153. https://doi.org/10.1016/j. gdata.2016.08.006

Hasegawa M, Kamada N, Jiao Y, Liu MZ, Nunez G, Inohara N (2012) Protective role of commensals against Clostridium difficile infection via an IL-1beta-mediated positive-feedback loop. J Immunol 189(6):3085-3091. https://doi.org/10.4049/jimmunol.1200821

Holland DB, Bojar RA, Jeremy AHT, Ingham E, Holland KT (2008) Microbial colonization of an in vitro model of a tissue engineered human skin equivalent-a novel approach. FEMS Microbiol Lett 279(1):110-115. https://doi.org/10.111 1/j.1574-6968.2007.01021.x

Hu T, Khambatta ZS, Hayden PJ et al (2010) Xenobiotic metabolism gene expression in the EpiDermin vitro 3D human epidermis model compared to human skin. Toxicol In Vitro 24(5):14501463. https://doi.org/10.1016/j.tiv.2010.03.013

Huang GT, Zhang HB, Kim D, Liu L, Ganz T (2002) A model for antimicrobial gene therapy: demonstration of human beta-defensin 2 antimicrobial activities in vivo. Hum Gene Ther 13(17):20172025. https://doi.org/10.1089/10430340260395875

Isaac NI, Philippe D, Nicholas A, Raoult D, Eric C (2019) Metaproteomics of the human gut microbiota: challenges and contributions to other OMICS. Clin Mass Spectrom 14:18-30. https:// doi.org/10.1016/j.clinms.2019.06.001

Jun JC, Jones MB, Oswald DM et al (2017) T cell-intrinsic TLR2 stimulation promotes IL-10 expression and suppressive activity by CD45RbHi T cells. PLoS One 12(7):e0180688. https://doi. org/10.1371/journal.pone.0180688
Kampfer AAM, Urban P, Gioria S, Kanase N, Stone V, KinsnerOvaskainen A (2017) Development of an in vitro co-culture model to mimic the human intestine in healthy and diseased state. Toxicol In Vitro 45(Pt 1):31-43. https://doi.org/10.1016/j. tiv.2017.08.011

Khalil E, Kretsos K, Kasting GB (2006) Glucose partition coefficient and diffusivity in the lower skin layers. Pharm Res 23(6):12271234. https://doi.org/10.1007/s11095-006-0141-9

Khayyira AS, Rosdina AE, Irianti MI, Malik A (2020) Simultaneous profiling and cultivation of the skin microbiome of healthy young adult skin for the development of therapeutic agents. Heliyon 6(4):e03700. https://doi.org/10.1016/j.heliyon.2020.e03700

Kim H-J, Kim H, Kim JJ et al (2018) Fragile skin microbiomes in megacities are assembled by a predominantly niche-based process. Sci Adv 4(3):e1701581. https://doi.org/10.1126/sciadv.1701581

Kubinak JL, Round JL (2012) Toll-like receptors promote mutually beneficial commensal-host interactions. PLoS Pathog 8(7):e1002785. https://doi.org/10.1371/journal.ppat.1002785

Lagler H, Sharif O, Haslinger I et al (2009) TREM-1 activation alters the dynamics of pulmonary IRAK-M expression in vivo and improves host defense during pneumococcal pneumonia. J Immunol 183(3):2027-2036. https://doi.org/10.4049/jimmu nol.0803862

Lai Y, Gallo RL (2009) AMPed up immunity: how antimicrobial peptides have multiple roles in immune defense. Trends Immunol 30(3):131-141. https://doi.org/10.1016/j.it.2008.12.003

Lai Y, Di Nardo A, Nakatsuji T et al (2009) Commensal bacteria regulate Toll-like receptor 3-dependent inflammation after skin injury. Nat Med 15(12):1377-1382. https://doi.org/10.1038/ nm.2062

Lai Y, Cogen AL, Radek KA et al (2010) Activation of TLR2 by a small molecule produced by Staphylococcus epidermidis increases antimicrobial defense against bacterial skin infections. J Investig Dermatol 130(9):2211-2221. https://doi.org/10.1038/ jid.2010.123

Lamichhane S, Sen P, Dickens AM, Oresic M, Bertram HC (2018) Gut metabolome meets microbiome: a methodological perspective to understand the relationship between host and microbe. Methods 149:3-12. https://doi.org/10.1016/j.ymeth.2018.04.029

Ley RE, Backhed F, Turnbaugh P, Lozupone CA, Knight RD, Gordon JI (2005) Obesity alters gut microbial ecology. Proc Natl Acad Sci USA 102(31):11070-11075. https://doi.org/10.1073/ pnas.0504978102

Linehan JL, Harrison OJ, Han SJ et al (2018) Non-classical immunity controls microbiota impact on skin immunity and tissue repair. Cell 172(4):784-796 e18 https://doi.org/10.1016/j. cell.2017.12.033

Lopez-Castejon G, Brough D (2011) Understanding the mechanism of IL-1beta secretion. Cytokine Growth Factor Rev 22(4):189-195. https://doi.org/10.1016/j.cytogfr.2011.10.001

Maboni G, Davenport R, Sessford K et al (2017) A novel 3D skin explant model to study anaerobic bacterial infection. Front Cell Infect Microbiol 7(404):404. https://doi.org/10.3389/fcimb .2017 .00404

Maier E, Anderson RC, Altermann E, Roy NC (2018) Live Faecalibacterium prausnitzii induces greater TLR 2 and TLR2/6 activation than the dead bacterium in an apical anaerobic co-culture system. Cell Microbiol 20(2):e12805. https://doi.org/10.1111/cmi.12805

Mason KM, Bigley NJ, Fink PS (1998) Development of a novel in vitro co-culture system for studying host response to native bacterial antigens. J Immunol Methods 211(1-2):147-158. https://doi. org/10.1016/s0022-1759(97)00200-7

McGeachy MJ, Chen Y, Tato CM et al (2009) The interleukin 23 receptor is essential for the terminal differentiation of interleukin 17-producing effector T helper cells in vivo. Nat Immunol 10(3):314-324. https://doi.org/10.1038/ni.1698 
Meisel JS, Sfyroera G, Bartow-McKenney C et al (2018) Commensal microbiota modulate gene expression in the skin. Microbiome 6(1):20. https://doi.org/10.1186/s40168-018-0404-9

Mohiti-Asli M, Pourdeyhimi B, Loboa EG (2014) Skin tissue engineering for the infected wound site: biodegradable PLA nanofibers and a novel approach for silver ion release evaluated in a 3D coculture system of keratinocytes and Staphylococcus aureus. Tissue Eng Part C Methods 20(10):790-797. https://doi. org/10.1089/ten.TEC.2013.0458

Naik S, Bouladoux N, Wilhelm C et al (2012) Compartmentalized control of skin immunity by resident commensals. Science 337(6098):1115-1119. https://doi.org/10.1126/science.1225152

Nakatsuji T, Chiang HI, Jiang SB, Nagarajan H, Zengler K, Gallo RL (2013) The microbiome extends to subepidermal compartments of normal skin. Nat Commun 4:1431. https://doi.org/10.1038/ ncomms 2441

Nawijn MC, Motta AC, Gras R, Shirinbak S, Maazi H, van Oosterhout AJ (2013) TLR-2 activation induces regulatory $\mathrm{T}$ cells and long-term suppression of asthma manifestations in mice. PLoS One 8(2):e55307. https://doi.org/10.1371/journ al.pone. 0055307

Neish AS (2009) Microbes in gastrointestinal health and disease. Gastroenterology 136(1):65-80. https://doi.org/10.1053/j.gastr o.2008.10.080

Netea MG, van de Veerdonk F, Verschueren I, van der Meer JW, Kullberg BJ (2008) Role of TLR1 and TLR6 in the host defense against disseminated candidiasis. FEMS Immunol Med Microbiol 52(1):118-123. https://doi.org/10.1111/j.1574695X.2007.00353.X

Nishimura M, Abiko Y, Kurashige Y et al (2004) Effect of defensin peptides on eukaryotic cells: primary epithelial cells, fibroblasts and squamous cell carcinoma cell lines. J Dermatol Sci 36(2):8795. https://doi.org/10.1016/j.jdermsci.2004.07.001

Nutsch KM, Hsieh CS (2012) T cell tolerance and immunity to commensal bacteria. Curr Opin Immunol 24(4):385-391. https://doi. org/10.1016/j.coi.2012.04.009

Oesch F, Fabian E, Guth K, Landsiedel R (2014) Xenobiotic-metabolizing enzymes in the skin of rat, mouse, pig, guinea pig, man, and in human skin models. Arch Toxicol 88(12):2135-2190. https://doi.org/10.1007/s00204-014-1382-8

Oppong GO, Rapsinski GJ, Newman TN, Nishimori JH, Biesecker SG, Tukel C (2013) Epithelial cells augment barrier function via activation of the Toll-like receptor 2/phosphatidylinositol 3-kinase pathway upon recognition of Salmonella enterica serovar Typhimurium curli fibrils in the gut. Infect Immun 81(2):478-486. https://doi.org/10.1128/IAI.00453-12

Park YJ, Lee HK (2017) The role of skin and orogenital microbiota in protective immunity and chronic immune-mediated inflammatory disease. Front Immunol 8(1955):1955. https://doi.org/10.3389/ fimmu.2017.01955

Percoco G, Merle C, Jaouen T et al (2013) Antimicrobial peptides and pro-inflammatory cytokines are differentially regulated across epidermal layers following bacterial stimuli. Exp Dermatol 22(12):800-806. https://doi.org/10.1111/exd.12259

Pfuhler S, Fautz R, Ouedraogo G et al (2014) The Cosmetics Europe strategy for animal-free genotoxicity testing: project status update. Toxicol In Vitro 28(1):18-23. https://doi.org/10.1016/j. tiv.2013.06.004

Platzek T, Lang C, Grohmann G, Gi US, Baltes W (1999) Formation of a carcinogenic aromatic amine from an azo dye by human skin bacteria in vitro. Hum Exp Toxicol 18(9):552-559. https://doi. org/10.1191/096032799678845061

Pluznick JL, Protzko RJ, Gevorgyan H et al (2013) Olfactory receptor responding to gut microbiota-derived signals plays a role in renin secretion and blood pressure regulation. Proc Natl Acad Sci USA 110(11):4410-4415. https://doi.org/10.1073/pnas.1215927110
Popov L, Kovalski J, Grandi G, Bagnoli F, Amieva MR (2014) Threedimensional human skin models to understand Staphylococcus aureus skin colonization and infection. Front Immunol 5:41. https://doi.org/10.3389/fimmu.2014.00041

Possemiers S, Bolca S, Verstraete W, Heyerick A (2011) The intestinal microbiome: a separate organ inside the body with the metabolic potential to influence the bioactivity of botanicals. Fitoterapia 82(1):53-66. https://doi.org/10.1016/j.fitote.2010.07.012

Preciado D, Caicedo E, Jhanjee R et al (2005) Pseudomonas aeruginosa lipopolysaccharide induction of keratinocyte proliferation, NF-kappa B, and cyclin D1 is inhibited by indomethacin. J Immunol 174(5):2964-2973. https://doi.org/10.4049/jimmu nol.174.5.2964

Rademacher F, Simanski M, Glaser R, Harder J (2018) Skin microbiota and human 3D skin models. Exp Dermatol 27(5):489-494. https ://doi.org/10.1111/exd.13517

Rademacher F, Simanski M, Hesse B et al (2019) Staphylococcus epidermidis activates aryl hydrocarbon receptor signaling in human keratinocytes: implications for cutaneous defense. J Innate Immun 11(2):125-135. https://doi.org/10.1159/000492162

Rai V, Agrawal DK (2017) The role of damage- and pathogen-associated molecular patterns in inflammation-mediated vulnerability of atherosclerotic plaques. Can J Physiol Pharmacol 95(10):1245-1253. https://doi.org/10.1139/cjpp-2016-0664

Rawls JF, Mahowald MA, Ley RE, Gordon JI (2006) Reciprocal gut microbiota transplants from zebrafish and mice to germ-free recipients reveal host habitat selection. Cell 127(2):423-433. https://doi.org/10.1016/j.cell.2006.08.043

Ren C, Zhang Q, de Haan BJ, Zhang H, Faas MM, de Vos P (2016) Identification of TLR2/TLR6 signalling lactic acid bacteria for supporting immune regulation. Sci Rep 6:34561. https://doi. org/10.1038/srep34561

Reynolds JM, Pappu BP, Peng J et al (2010) Toll-like receptor 2 signaling in $\mathrm{CD} 4(+) \mathrm{T}$ lymphocytes promotes $\mathrm{T}$ helper 17 responses and regulates the pathogenesis of autoimmune disease. Immunity 32(5):692-702. https://doi.org/10.1016/j.immuni.2010.04.010

Ridaura VK, Bouladoux N, Claesen J et al (2018) Contextual control of skin immunity and inflammation by Corynebacterium. J Exp Med 215(3):785-799. https://doi.org/10.1084/jem.20171079

Ross AA, Rodrigues Hoffmann A, Neufeld JD (2019) The skin microbiome of vertebrates. Microbiome 7(1):79. https://doi.org/10.1186/ s40168-019-0694-6

Round JL, Palm NW (2018) Causal effects of the microbiota on immune-mediated diseases. Sci Immunol 3(20):eaao1603. https ://doi.org/10.1126/sciimmunol.aao1603

Round JL, Lee SM, Li J et al (2011) The Toll-like receptor 2 pathway establishes colonization by a commensal of the human microbiota. Science 332(6032):974-977. https://doi.org/10.1126/scien ce. 1206095

Sajib S, Zahra FT, Lionakis MS, German NA, Mikelis CM (2018) Mechanisms of angiogenesis in microbe-regulated inflammatory and neoplastic conditions. Angiogenesis 21(1):1-14. https://doi. org/10.1007/s10456-017-9583-4

Sazal MR, Stebliankin V, Mathee K, Narasimhan G (2020) Causal inference in microbiomes using intervention calculus. BioRxiv. https://doi.org/10.1101/2020.02.28.970624

Scharschmidt TC, Fischbach MA (2013) What lives on our skin: ecology, genomics and therapeutic opportunities of the skin microbiome. Drug Discov Today Dis Mech 10(3-4):e83-e89. https:// doi.org/10.1016/j.ddmec.2012.12.003

Schommer NN, Gallo RL (2013) Structure and function of the human skin microbiome. Trends Microbiol 21(12):660-668. https://doi. org/10.1016/j.tim.2013.10.001

Sender R, Fuchs S, Milo R (2016) Revised estimates for the number of human and bacteria cells in the body. PLoS Biol 14(8):e1002533. https://doi.org/10.1371/journal.pbio.1002533 
Shin JE, Choi Y (2010) Treponema denticola suppresses expression of human beta-defensin-2 in gingival epithelial cells through inhibition of TNFalpha production and TLR2 activation. Mol Cells 29(4):407-412. https://doi.org/10.1007/s10059-010-0048-5

Shin HS, Lee JH, Paek SH, Jung YW, Ha UH (2013) Pseudomonas aeruginosa-dependent upregulation of TLR2 influences host responses to a secondary Staphylococcus aureus infection. Pathog Dis 69(2):149-156. https://doi.org/10.1111/2049-632X.12074

Sousa T, Paterson R, Moore V, Carlsson A, Abrahamsson B, Basit AW (2008) The gastrointestinal microbiota as a site for the biotransformation of drugs. Int J Pharm 363(1-2):1-25. https://doi. org/10.1016/j.ijpharm.2008.07.009

Sowada J, Schmalenberger A, Ebner I, Luch A, Tralau T (2014) Degradation of benzo $[a]$ pyrene by bacterial isolates from human skin. FEMS Microbiol Ecol 88(1):129-139. https://doi. org/10.1111/1574-6941.12276

Sowada J, Lemoine L, Schon K, Hutzler C, Luch A, Tralau T (2017) Toxification of polycyclic aromatic hydrocarbons by commensal bacteria from human skin. Arch Toxicol 91(6):2331-2341. https ://doi.org/10.1007/s00204-017-1964-3

Staley C, Kaiser T, Beura LK et al (2017) Stable engraftment of human microbiota into mice with a single oral gavage following antibiotic conditioning. Microbiome 5(1):87. https://doi.org/10.1186/ s40168-017-0306-2

Stappenbeck TS, Hooper LV, Gordon JI (2002) Developmental regulation of intestinal angiogenesis by indigenous microbes via Paneth cells. Proc Natl Acad Sci USA 99(24):15451-15455. https://doi. org/10.1073/pnas.202604299

Steglinska A, Jachowicz A, Szulc J et al (2019) Factors influencing microbiological biodiversity of human foot skin. Int J Environ Res Public Health 16(18):3503. https://doi.org/10.3390/ijerp h16183503

Steinz K, Schubert S, Harder J, Gerdes S, Mrowietz U, Glaser R (2014) Bacterial soft tissue infection in psoriasis despite induction of epidermal antimicrobial peptides. Exp Dermatol 23(11):862864. https://doi.org/10.1111/exd.12538

Stingley RL, Zou W, Heinze TM, Chen H, Cerniglia CE (2010) Metabolism of azo dyes by human skin microbiota. J Med Microbiol 59(Pt 1):108-114. https://doi.org/10.1099/jmm.0.012617-0

Takai T, Chen X, Xie Y et al (2014) TSLP expression induced via Toll-like receptor pathways in human keratinocytes. Methods Enzymol 535:371-387. https://doi.org/10.1016/B978-0-12397925-4.00021-3

Tessarz AS, Cerwenka A (2008) The TREM-1/DAP12 pathway. Immunol Lett 116(2):111-116. https://doi.org/10.1016/j.imlet 2007.11.021

Tralau T, Yang EC, Tralau C, Cook AM, Küpper FC (2011) Why two are not enough: degradation of $p$-toluenesulfonate by a bacterial community from a pristine site in Moorea, French Polynesia. FEMS Microbiol Lett 316(2):123-129. https://doi.org/10.111 1/j.1574-6968.2010.02207.x

Tralau T, Sowada J, Luch A (2015) Insights on the human microbiome and its xenobiotic metabolism: what is known about its effects on human physiology? Expert Opin Drug Metab Toxicol 11(3):411425. https://doi.org/10.1517/17425255.2015.990437

Tsai T, Veitinger S, Peek I et al (2017) Two olfactory receptorsOR2A4/7 and OR51B5-differentially affect epidermal proliferation and differentiation. Exp Dermatol 26(1):58-65. https://doi. org/10.1111/exd.13132

Turnbaugh PJ, Ley RE, Hamady M, Fraser-Liggett CM, Knight R, Gordon JI (2007) The human microbiome project. Nature 449(7164):804-810. https://doi.org/10.1038/nature06244

Ueda Y, Kayama H, Jeon SG et al (2010) Commensal microbiota induce LPS hyporesponsiveness in colonic macrophages via the production of IL-10. Int Immunol 22(12):953-962. https://doi. org/10.1093/intimm/dxq449
Ullah S, Hamade F, Bubniene U et al (2018) In-vitro model for assessing glucose diffusion through skin. Biosens Bioelectron 110:175-179. https://doi.org/10.1016/j.bios.2018.03.039

van der Krieken DA, Ederveen TH, van Hijum SA et al (2016) An in vitro model for bacterial growth on human stratum corneum. Acta Derm Venereol 96(7):873-879. https://doi. org/10.2340/00015555-2401

van Maren WW, Jacobs JF, de Vries IJ, Nierkens S, Adema GJ (2008) Toll-like receptor signalling on Tregs: to suppress or not to suppress? Immunology 124(4):445-452. https://doi.org/10.111 1/j.1365-2567.2008.02871.x

Varanat M, Haase EM, Kay JG, Scannapieco FA (2017) Activation of the TREM-1 pathway in human monocytes by periodontal pathogens and oral commensal bacteria. Mol Oral Microbiol 32(4):275-287. https://doi.org/10.1111/omi.12169

Veldhoen M, Hirota K, Westendorf AM et al (2008) The aryl hydrocarbon receptor links TH17-cell-mediated autoimmunity to environmental toxins. Nature 453(7191):106-109. https://doi. org/10.1038/nature06881

Viggor S, Jõesaar M, Soares-Castro P et al (2020) Microbial metabolic potential of phenol degradation in wastewater treatment plant of crude oil refinery: analysis of metagenomes and characterization of isolates. Microorganisms 8(5):652. https://doi.org/10.3390/ microorganisms 8050652

Vrancken G, Gregory AC, Huys GRB, Faust K, Raes J (2019) Synthetic ecology of the human gut microbiota. Nat Rev Microbiol 17(12):754-763. https://doi.org/10.1038/s41579-019-0264-8

Walter J, Armet AM, Finlay BB, Shanahan F (2020) Establishing or exaggerating causality for the gut microbiome: lessons from human microbiota-associated rodents. Cell 180(2):221-232. https://doi.org/10.1016/j.cell.2019.12.025

Wang M, Donovan SM (2015) Human microbiota-associated swine: current progress and future opportunities. ILAR J 56(1):63-73. https://doi.org/10.1093/ilar/ilv006

Wang Q, Cui S, Zhou L et al (2019) Effect of cosmetic chemical preservatives on resident flora isolated from healthy facial skin. J Cosmet Dermatol 18(2):652-658. https://doi.org/10.1111/ jocd. 12822

Wanke I, Steffen H, Christ C et al (2011) Skin commensals amplify the innate immune response to pathogens by activation of distinct signaling pathways. J Investig Dermatol 131(2):382-390. https ://doi.org/10.1038/jid.2010.328

Wills JW, Hondow N, Thomas AD et al (2016) Genetic toxicity assessment of engineered nanoparticles using a 3D in vitro skin model (EpiDerm). Part Fibre Toxicol 13(1):50. https://doi.org/10.1186/ s12989-016-0161-5

Wu M, Peng A, Sun M et al (2011) TREM-1 amplifies corneal inflammation after Pseudomonas aeruginosa infection by modulating Toll-like receptor signaling and Th1/Th2-type immune responses. Infect Immun 79(7):2709-2716. https://doi. org/10.1128/IAI.00144-11

$\mathrm{Xu} \mathrm{C}, \mathrm{Lu}$ Y, Zheng X et al (2017) TLR2 expression in peripheral $\mathrm{CD} 4+\mathrm{T}$ cells promotes Th17 response and is associated with disease aggravation of hepatitis B virus-related acute-onchronic liver failure. Front Immunol 8(1609):1609. https://doi. org/10.3389/fimmu.2017.01609

Yadav M, Verma MK, Chauhan NS (2018) A review of metabolic potential of human gut microbiome in human nutrition. Arch Microbiol 200(2):203-217. https://doi.org/10.1007/s0020 3-017-1459-x

Young M, Artsatbanov V, Beller HR et al (2010) Genome sequence of the Fleming strain of Micrococcus luteus, a simple free-living actinobacterium. J Bacteriol 192(3):841-860. https://doi. org/10.1128/JB.01254-09 
Zhao RR, Yang XF, Dong J et al (2015) Toll-like receptor 2 promotes $\mathrm{T}$ helper 17 cells response in hepatitis B virus infection. Int J Clin Exp Med 8(5):7315-7323

Zielinski CE, Mele F, Aschenbrenner D et al (2012) Pathogen-induced human TH17 cells produce IFN-gamma or IL-10 and are regulated by IL-1beta. Nature 484(7395):514-518. https://doi. org/10.1038/nature10957
Publisher's Note Springer Nature remains neutral with regard to jurisdictional claims in published maps and institutional affiliations. 